\title{
Atypical presentation of fibroepithelial polyp: a report of two cases
}

\author{
Mustafa Vatansever', Erdem Dinç², Özer Dursun², Özgün Öcalan Oktay², Rabia Arpacı \\ 1. Department of Ophthalmology, Toros State Hospital, Mersin, Turkey. \\ 2. Department of Ophthalmology, Faculty of Medicine, Mersin University, Mersin, Turkey. \\ 3. Department of Pathology, Faculty of Medicine, Mersin University, Mersin, Turkey.
}

Apresentação atípica de pólipo fibroepitelial: um relato de dois casos

\begin{abstract}
I Fibroepithelial polyps are benign non-epithelial tumors arising from mesodermal tissue and are commonly found on the skin. They can develop on the eyelid and surrounding area and rarely appear at other sites. While most cutaneous cases are diagnosed incidentally, the lesions may be symptomatic based on their location. The etiology of fibroepithelial polyps is not fully understood but may involve trauma, chronic irritation, allergic factors, and developmental or congenital causes. Although fibroepithelial polyps are benign lesions, they can be malignant in extremely rare cases. Herein we discuss 2 cases of fibroepithelial polyp with an atypical presentation and their treatment.
\end{abstract}

Keywords: Neoplasms, fibroepithelial; Polyps; Eyelids; Dermoid cyst; Case report

RESUMO | Pólipos fibroepiteliais são tumores benignos não-epiteliais que surgem do tecido mesodérmico e são comumente encontrados na pele. Eles podem se desenvolver na pálpebra e na área adjacente, e raramente aparecem em outros locais. Embora a maioria dos casos cutâneos seja diagnosticada incidentalmente, as lesões podem ser sintomáticas com base em sua localização. A etiologia dos pólipos fibroepiteliais não é completamente compreendida, mas pode envolver trauma, irritação crônica, fatores alérgicos e causas de desenvolvimento ou congênitas. Apesar dos pólipos fibroepiteliais serem lesões benignas, podem ser malignos em casos extremamente raros. Aqui discutimos 2 casos de pólipo fibroepitelial com uma apresentação atípica e seu tratamento.

Descritores: Neoplasias, fibroepitelial; Pólipos; Pálpebras; Cisto dermóide; Relato de caso

Submitted for publication: June 12, 2018

Accepted for publication: November 15, 2018

Funding: No specific financial support was available for this study.

Disclosure of potential conflicts of interest: None of the authors have any potential conflicts of interest to disclose.

Corresponding author: Mustafa Vatansever.

Toros State Hospital, Department of Ophthalmology, Mersin, Turkey

E-mail: vatansevermustafa@hotmail.com

\section{INTRODUCTION}

Fibroepithelial polyps (FEP) are common benign, cutaneous, non-epithelial tumors of mesodermal origin that occur on the eyelid and surrounding area. A histopathologic study investigating eyelid lesions determined the incidence of FEPs to be $8.6 \%^{(1)}$. Rarely, FEPs have been reported in locations including the ureteropelvic system, genitals, bronchi, tonsils, and outer ear canal ${ }^{(2-6)}$. While most cutaneous lesions are diagnosed incidentally, they may be symptomatic depending on their location. Although the etiology of FEP has not been completely elucidated, the etiology may involve trauma, chronic irritation, infections, allergic factors, or developmental or congenital causes. In this report, we discuss 2 cases of FEP with an atypical presentation and their treatment.

\section{CASE REPORTS}

\section{Case 1}

A 57-year-old male was treated in our clinic for swelling of the nasal conjunctiva in the right eye. He could not recall how long the swelling had endured. The patient had no history of systemic disease, trauma, or ocular disease. Best-corrected visual acuity was 20/20 in both eyes. Examination of the anterior segment revealed a movable and nonpigmented conjunctival mass in the nasal aspect of the right eye. The mass was not substantially raised and did not extend to the limbus. Anterior segment examination of the left eye was normal, with no signs of pathology in either eye on fundus examination. The mass was excised under local anesthesia and the underlying sclera was treated with cryotherapy. The excision area was covered with amniotic membrane, and the excised tissue received pathological examination. Topical antibiotic and steroid drops were prescribed for 
postoperative treatment. No complications were noted during follow-up. Pathology results indicated that the mass was an FEP and had been removed in its entirety (Figure 1). No further treatment was advised, and there was no recurrence during follow-up.

\section{Case 2}

A 2-year-old male patient presented to our clinic with numerous swellings around the right lower eyelid and ocular surface. The patient had a history of mass lesions since birth, and he had previously received surgery for a nasal mass at another center. His discharge records described a mass lesion originating in the lower concha, which was removed and diagnosed as FEP based on pathologic examination. A mass lesion at the right lower lid margin, another mass lesion in the temporal aspect of the right eye extending beyond the limbus onto the cornea, and swelling and crusting of the nasal aspect of the eyelid were revealed on examination (Figure 2). Examination of the left eye was normal, and fundus examination revealed no pathological findings in either eye. The mass at the right lower lid margin and the one extending toward the cornea were excised under general anesthesia. Swelling in the nasal aspect of the lower eyelid was identified as chalazion. Curettage was performed in addition to a pathological evaluation of the excised tissue. The patient was treated with topical antibiotic and steroid drops postoperatively. No compli-
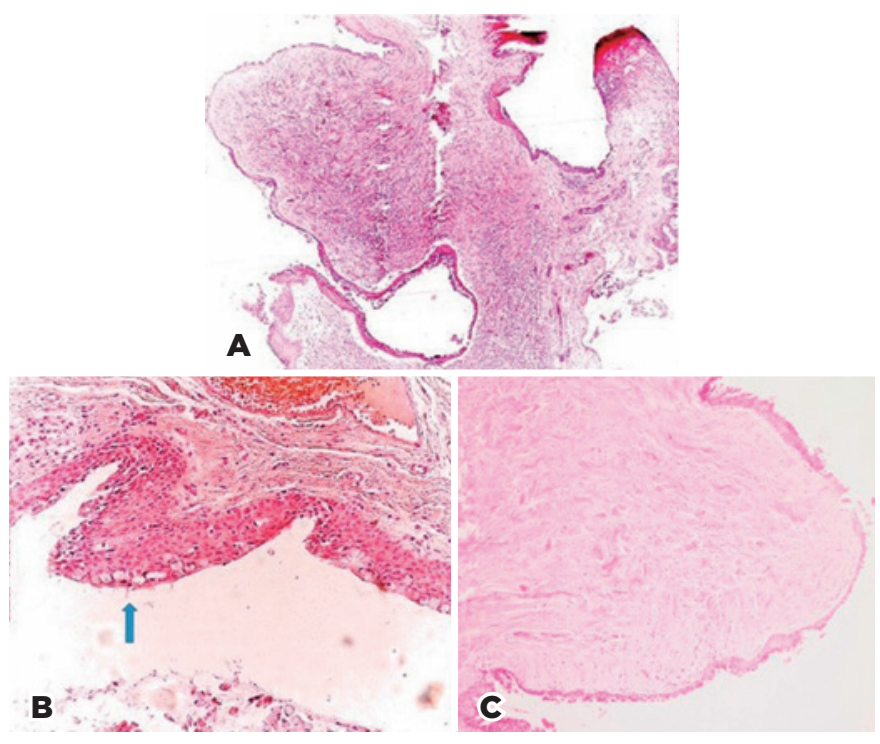

Figure 1. Conjunctival polypoid lesion (H\&E, 4Ox). (A) Squamous epithelial hyperplasia containing goblet cells; (B) (Arrow) (H\&E, 200x); and (C) Higher magnification of the lamina propria. cations were observed during follow-up. The pathology report indicated a benign FEP removed from the lid margin, a dermoid extending to the corneal surface, and complete excision of the entire area (Figure 3). No further treatment was recommended, and no recurrence was observed during follow-up.

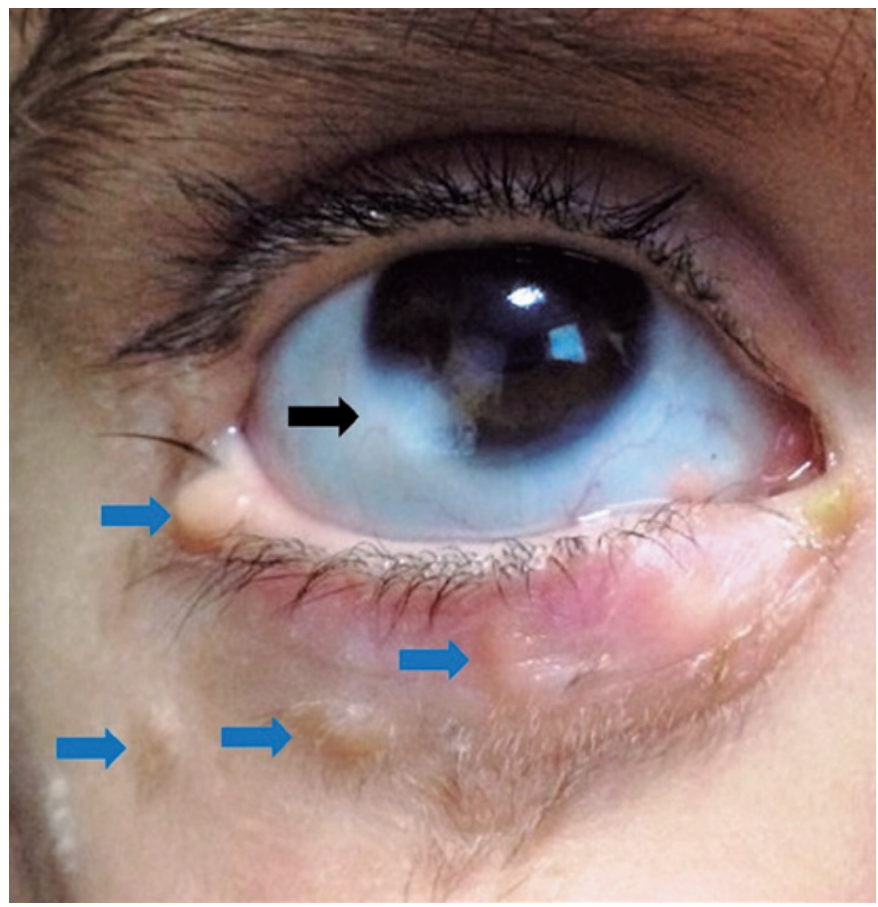

Figure 2. Multiple lesions are seen at and around the lower eyelid margin (blue arrows), and a limbal dermoid extends past the limbus toward the corneal surface (black arrow).

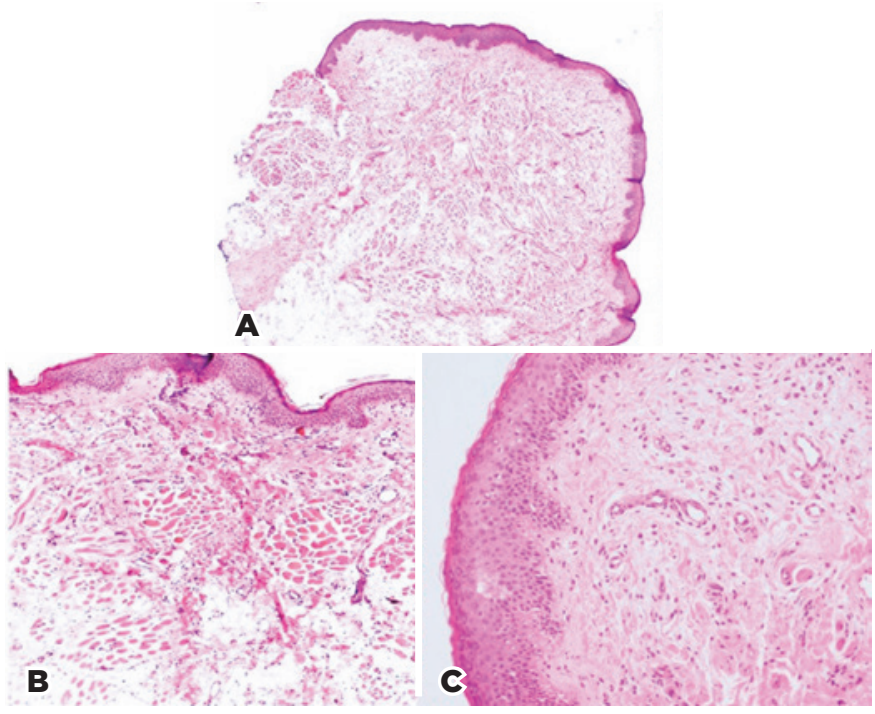

Figure 3. Benign polypoid lesion including hyperplastic squamous epithelium. (A) Congestion, fibrosis, and stromal edema (H\&E, 4Ox); (B) (H\&E, 200×); (C) Lid margin lesion (H\&E, 100×). 


\section{DISCUSSION}

Fibroepithelial polyps are common cutaneous lesions, but cases with atypical presentation have been reported. In the first presented case, a conjunctival mass was removed and diagnosed as FEP based on pathological examination. To our knowledge, this is the first case of FEP reported in the literature in this location. Yoon et al. published a major series on conjunctival masses in adults, revealing that the most common benign lesions were pterygium (18\%), dysplasia (7\%), inflammation (nonspecific and nongranulomatous, 7\%), and epithelial inclusion cyst (6\%). The most common malignant lesions were SCC (4\%), melanoma (3\%), and sebaceous cell carcinoma $(<1 \%)^{(7)}$. Moreover, Dalvin et al. reported that most conjunctival tumors (94\%) in their study were benign. Melanocytic lesions accounted for the majority (86\%) of benign lesions, with adjusted incidence rates of 10.8 for complexion-associated melanosis, 49.7 for nevus, and 44.1 for primary acquired melanosis. Malignant lesions were rare $(6 \%)$ including 6 cases of melanoma, 21 cases of ocular surface squamous neoplasia (OSSN), 1 case of Langerhans cell histiocytosis, and 2 cases of lymphoma ${ }^{(8)}$. Malignant epithelial lesions were common in older patients ${ }^{(9)}$.

Mass location in the second case was not atypical. However, the presence of a limbal dermoid accompanying the FEP was an interesting presentation. Seymenoğlu et al. reported FEP with limbal dermoid in a patient with Goldenhar syndrome ${ }^{(10)}$. The patient in the present case did not have such a syndrome. Another unique feature of the second case was that a mass previously excised from the patient's nasal cavity was also identified as an FEP. This is the first reported case of such an occurrence in the literature. Published data on childhood conjunctival mass are very limited. Shields et al found that conjunctival tumors in children were usually benign (97\%) and most commonly presented as nevus, benign reactive lymphoid hyperplasia, primary acquired melanosis, dermoid and dermolipoma, papilloma, choristoma, hemangioma, and lymphangioma. Malignant conjunctival tumors, including melanoma and lymphoma, are rare in children $(3 \%)^{(11)}$.

Although the question why FEP develops is not fully understood, several possible causes have been proposed. The first presented case can be considered idiopathic because the patient did not have a history of ocular disease or trauma. However, in the second case, the formation of multiple masses in different locations and their presence since birth suggests congenital origins.

Although FEP is a benign lesion, this lesion can be malignant in extremely rare cases. Eads et al. reported that only 5 of 1,335 lesions receiving a histopathologic analysis with a prediagnosis of FEP were malignant ${ }^{(12)}$. Therefore, a definitive diagnosis should be made based on pathologic examination of the excised tissue, as in the presented cases. In the first case, the conjunctival mass was excised, and prophylactic cryotherapy of the underlying sclera was applied due to the suspicion of malignancy. In the second case, the mass at the lid margin was removed and healed by secondary intention after ensuring hemostasis. The patients did not experience complications or recurrence during follow-up.

In conclusion, remembering that FEP may appear at various ocular and periocular sites and may also be accompanied by lesions located at different sites with different histopathologic characteristics is important.

\section{REFERENCES}

1. Paul S, Vo DT, Silkiss RZ. Malignant and benign eyelid lesions in San Francisco: study of a diverse urban population. Am J Clin Med. 2011;8:40-6.

2. Ludwig DJ, Buddingh KT, Kums JJ, Kropman RF, Roshani H, Hirdes WH. Treatment and outcome of fibroepithelial ureteral polyps: a systematic literature review. Can Urol Assoc J. 2015;9(9-10):E361-7.

3. Raphael Avidime A, Usman H. Bilateral giant fibroepithelial labial mass: a case report. J Obstet Gynaecol Can. 2017;39(7):564-6.

4. Melo RC, Ribeiro C, Sanches A, Oliveira A. A rare benign tumor of tracheobronchial tree: endobronchial fibroepithelial polyp. Rev Port Pneumol. 2015;21(4):221-2.

5. Thomas P, Rai P, Meena R. Fibroepithelial polyp of external auditory canal. Eur Ann Otorhinolaryngol Head Neck Dis. 2017; 134(2):141-2.

6. Telugu RB, Ashish G. Fibroepithelial polyp of the tonsil: report of a rare case. J Clin Diagn Res. 2015;9(12):ED17-8.

7. Yoon YD, Grossniklaus H. Tumors of the cornea and conjunctiva. Curr Opin Ophthalmol. 1997;8(4):55-8.

8. Dalvin LA, Salomao DR, Patel SV. Population-based incidence of conjunctival tumours in Olmsted Country, Minnesota. Br J Ophthalmol. 2018;101(12):1728-34.

9. Tost F, Evert M. [Conjunctival tumors in elderly patients]. Klin Monbl Augenheilkd. 2010;227(1):33-42. German.

10. Seymenoğlu G, Başer E, Tansuğ N, Demireli P. An unusual association of Goldenhar syndrome. Int Ophthalmol. 2013;33(1):91-4.

11. Shields CL, Sioufi K, Alset AE, Boal NS, Casey MG, Knapp AN, et al. Clinical features differentiating benign from malignant conjunctival tumors in children. JAMA Ophthalmol. 2017;135(3):215-24.

12. Eads T), Chuang TY, Fabre VC, Farmer ER, Hood AF. The utility of submitting fibroepithelial polps for histological examination. Arch Dermatol. 1996;132(12):1459-62. 